\title{
Front Matter: Volume 8727
}

, "Front Matter: Volume 8727," Proc. SPIE 8727, Advanced Photon Counting Techniques VII, 872701 (6 June 2013); doi: 10.1117/12.2031971

SPIE Event: SPIE Defense, Security, and Sensing, 2013, Baltimore, Maryland, United States 


\section{PROCEEDINGS OF SPIE}

\section{Advanced Photon Counting Techniques VII}

Mark A. Itzler

Joe C. Campbell

Editors

1-2 May 2013

Baltimore, Maryland, United States

Sponsored and Published by

SPIE 
The papers included in this volume were part of the technical conference cited on the cover and title page. Papers were selected and subject to review by the editors and conference program committee. Some conference presentations may not be available for publication. The papers published in these proceedings reflect the work and thoughts of the authors and are published herein as submitted. The publisher is not responsible for the validity of the information or for any outcomes resulting from reliance thereon.

Please use the following format to cite material from this book:

Author(s), "Title of Paper," in Advanced Photon Counting Techniques VII, edited by Mark A. Itzler, Joe C. Campbell, Proceedings of SPIE Vol. 8727 (SPIE, Bellingham, WA, 2013) Article CID Number.

ISSN: 0277-786X

ISBN: 9780819495181

Published by

SPIE

P.O. Box 10, Bellingham, Washington 98227-0010 USA

Telephone +1 3606763290 (Pacific Time) · Fax +1 3606471445

SPIE.org

Copyright @ 2013 , Society of Photo-Optical Instrumentation Engineers.

Copying of material in this book for internal or personal use, or for the internal or personal use of specific clients, beyond the fair use provisions granted by the U.S. Copyright Law is authorized by SPIE subject to payment of copying fees. The Transactional Reporting Service base fee for this volume is $\$ 18.00$ per article (or portion thereof), which should be paid directly to the Copyright Clearance Center (CCC), 222 Rosewood Drive, Danvers, MA 01923. Payment may also be made electronically through CCC Online at copyright.com. Other copying for republication, resale, advertising or promotion, or any form of systematic or multiple reproduction of any material in this book is prohibited except with permission in writing from the publisher. The CCC fee code is $0277-786 \mathrm{X} / 13 / \$ 18.00$.

Printed in the United States of America.

Publication of record for individual papers is online in the SPIE Digital Library.

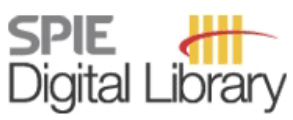

SPIEDigitalLibrary.org

Paper Numbering: Proceedings of SPIE follow an e-First publication model, with papers published first online and then in print and on CD-ROM. Papers are published as they are submitted and meet publication criteria. A unique, consistent, permanent citation identifier (CID) number is assigned to each article at the time of the first publication. Utilization of CIDs allows articles to be fully citable as soon as they are published online, and connects the same identifier to all online, print, and electronic versions of the publication. SPIE uses a six-digit CID article numbering system in which:

- The first four digits correspond to the SPIE volume number.

- The last two digits indicate publication order within the volume using a Base 36 numbering

system employing both numerals and letters. These two-number sets start with 00, 01, 02, 03, 04,

05, 06, 07, 08, 09, 0A, OB ... 0Z, followed by 10-1Z, 20-2Z, etc.

The CID Number appears on each page of the manuscript. The complete citation is used on the first page, and an abbreviated version on subsequent pages. Numbers in the index correspond to the last two digits of the six-digit CID Number. 


\section{Contents}

vii Conference Committee

\section{APPLICATIONS I: SINGLE PHOTON COMMUNICATIONS AND TCSPC}

872702 Hyperentanglement for quantum telecommunications (Invited Paper) [8727-1]

N. A. Peters, A. Agarwal, T. E. Chapuran, P. Toliver, Applied Communication Sciences (United States)

\section{SUPERCONDUCTING SPDS I}

872708 Technologies for superconducting nanowire single-photon detector array system (Invited Paper) [8727-8]

S. Miki, T. Yamashita, H. Terai, K. Makise, Z. Wang, National Institute of Information and Communications Technology (Japan)

8727 OA Superconducting nanowire single-photon detectors integrated with waveguide circuits for quantum information science (Invited Paper) [8727-10]

A. Gaggero, Istituto di Fotonica e Nanotecnologie, CNR (Italy); D. Sahin, Technische Univ. Eindhoven (Netherlands); F. Mattioli, R. Leoni, Istituto di Fotonica e Nanotecnologie, CNR (Italy); G. Frucci, S. Jahanmirinejad, J. P. Sprengers, Technische Univ. Eindhoven

(Netherlands); J. Beetz, M. Lermer, S. Höfling, M. Kamp, Julius-Maximilians-Univ. Würzburg

(Germany); A. Fiore, Technische Univ. Eindhoven (Netherlands)

\section{SUPERCONDUCTING SPDS II}

8727 OB Multiphoton detection in superconducting nanowires: nonlinear optics in the detector (Invited Paper) [8727-11]

Z. Zhou, G. Frucci, Technische Univ. Eindhoven (Netherlands); F. Mattioli, A. Gaggero,

R. Leoni, Istituto di Fotonica e Nanotecnologie, CNR (Italy); S. Jahanmirinejad, T. B. Hoang,

A. Fiore, Technische Univ. Eindhoven (Netherlands)

\section{SPADS I: GATED OPERATION}

8727 OF Gigahertz-gated InGaAs SPAD system with avalanche charge sensitivity approaching the fundamental limit (Invited Paper) [8727-15]

A. Restelli, Joint Quantum Institute (United States); J. C. Bienfang, A. L. Migdall, Joint Quantum Institute (United States) and National Institute of Standards and Technology (United States)

8727 OG Advantages of gated silicon single photon detectors [8727-16]

M. Legré, ID Quantique SA (Switzerland); T. Lunghi, Univ. of Geneva (Switzerland); D. Stucki, ID Quantique SA (Switzerland); H. Zbinden, Univ. of Geneva (Switzerland) 
$8727 \mathrm{OH} \quad$ Balanced detection in single photon counting [8727-17]

Z. Lu, W. Sun, J. Campbell, Univ. of Virginia (United States); X. Jiang, M. A. Itzler, Princeton Lightwave, Inc. (United States)

8727 Ol Near-IR photon number resolving detector design [8727-18]

J. Bogdanski, E. H. Huntington, The Univ. of New South Wales (Australia)

8727 OK Precise Monte Carlo simulation of single-photon detectors [8727-33]

M. Stipčević, Duke Univ. (United States) and Institut Ruder Boškovic (Croatia);

D. J. Gauthier, Duke Univ. (United States)

SPADS II: ARRAYS

8727 OL MiSPIA: microelectronic single-photon 3D imaging arrays for low-light high-speed safety and security applications (Invited Paper) [8727-20]

F. Zappa, A. Tosi, Politecnico di Milano (Italy)

8727 OM New silicon technologies enable high-performance arrays of single photon avalanche diodes (Invited Paper) [8727-21]

A. Gulinatti, I. Rech, Politecnico di Milano (Italy); P. Maccagnani, Istituto per la Microelettronica e Microsistemi, CNR (Italy); S. Cova, M. Ghioni, Politecnico di Milano (Italy) and Micro Photon Devices S.r.l. (Italy)

8727 ON Compound semiconductor SPAD arrays (Invited Paper) [8727-22]

E. S. Harmon, M. Naydenkov, J. T. Hyland, LightSpin Technologies, Inc. (United States)

SPADS III: NOVEL STRUCTURES

8727 OP Multiple gain mechanisms integrated in APDs biased below breakdown for sensitivity improvement (Invited Paper) [8727-24]

S. N. Rahman, D. Hall, Univ. of California, San Diego (United States); Z. Mei, Beijing Institute of Technology (China) and Univ. of California, San Diego (United States); Y. H. LO, Univ. of California, San Diego (United States)

\section{QUANTUM STRUCTURES FOR SPC}

8727 OS Single nanocrystal spectroscopy approaches for investigation of emission efficiency and recombination dynamics of multi-excitons (Invited Paper) [8727-27]

B. D. Mangum, Y.-S. Park, Y. Ghosh, J. A. Hollingsworth, H. Htoon, Los Alamos National Lab. (United States)

PMTS AND PHOTON COUNTING IMAGERS

8727 OT Performance of a compact position-sensitive photon counting detector with image charge coupling to an air-side anode (Invited Paper) [8727-28]

O. Jagutzki, A. Czasch, S. Schössler, RoentDek Handels GmbH (Germany) 
8727 OU Study on the detection efficiency of gaseous photomultipliers [8727-30]

G. Baishali, Indian Institute of Science (India); V. Radhakrishna, V. Koushal, K. Rakhee, ISRO Satellite Ctr. (India); K. Rajanna, Indian Institute of Science (India)

\section{POSTER SESSION}

8727 OW High speed multichannel time-correlated single photon counting electronics based on SiGe integrated time-to-digital converters [8727-32]

M. Wahl, T. Röhlicke, H.-J. Rahn, V. Buschmann, PicoQuant GmbH (Germany); N. Bertone, PicoQuant Photonics North America Inc. (Canada); G. Kell, Fachhochschule Brandenburg (Germany)

Author Index 


\section{Conference Committee}

Symposium Chair

Kenneth R. Israel, Major General (USAF Retired) (United States)

Symposium Cochair

David A. Whelan, Boeing Defense, Space, and Security (United States)

Conference Chair

Mark A. Itzler, Princeton Lightwave, Inc. (United States)

Conference Cochair

Joe C. Campbell, University of Virginia (United States)

Conference Program Committee

Gerald S. Buller, Heriot-Watt University (United Kingdom)

Sergio Cova, Politecnico di Milano (Italy)

William H. Farr, Jet Propulsion Laboratory (United States)

Robert H. Hadfield, Heriot-Watt University (United Kingdom)

Majeed Hayat, The University of New Mexico (United States)

Michael A. Krainak, NASA Goddard Space Flight Center (United States)

Robert A. Lamb, SELEX Galileo Ltd. (United Kingdom)

K. Alex McIntosh, MIT Lincoln Laboratory (United States)

Alan L. Migdall, National Institute of Standards and Technology (United States)

Michael Wahl, PicoQuant GmbH (Germany)

Hugo Zbinden, University of Geneva (Switzerland)

Session Chairs

1 Applications I: Single Photon Communications and TCSPC

Mark A. Itzler, Princeton Lightwave, Inc. (United States)

2 Applications II: Single Photon Laser Radar

Mark A. Itzler, Princeton Lightwave, Inc. (United States)

3 Superconducting SPDs I

Joe C. Campbell, University of Virginia (United States) 
4 Superconducting SPDs II

Robert H. Hadfield, Heriot-Watt University (United Kingdom)

5 SPADs I: Gated Operation

Simon Verghese, MIT Lincoln Laboratory (United States)

6 SPADs II: Arrays

Joe C. Campbell, University of Virginia (United States)

7 SPADs III: Novel Structures

Mark A. Itzler, Princeton Lightwave, Inc. (United States)

8 Quantum Structures for SPC

Alan L. Migdall, National Institute of Standards and Technology (United States)

9 PMTs and Photon Counting Imagers

Alan L. Migdall, National Institute of Standards and Technology (United States) 